\title{
Etseskade av våt sement
}

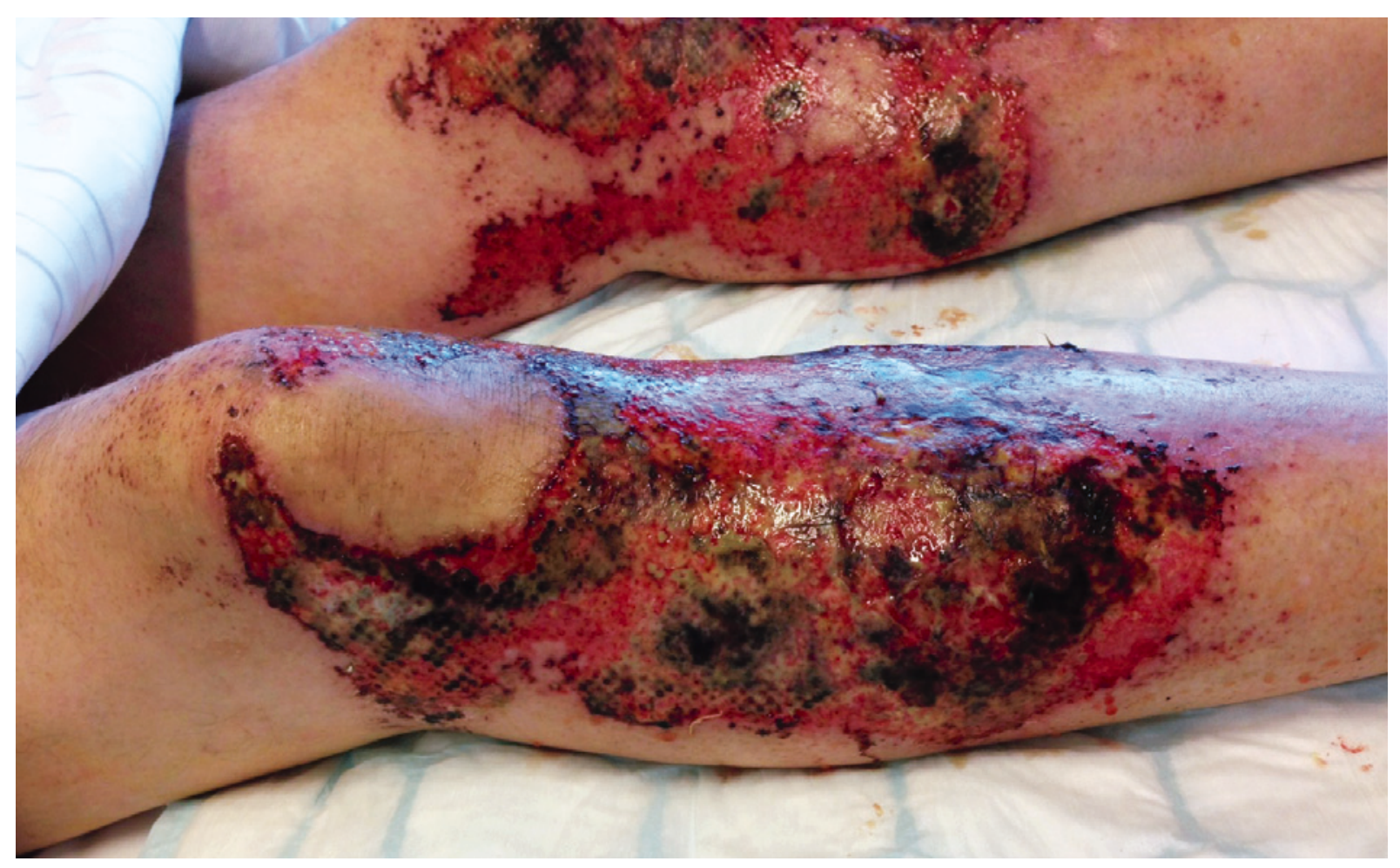

En stort sett frisk mann i 50-årene ble innlagt ved kirurgisk avdeling med etseskade på begge legger etter arbeid med våt sement som trakk igjennom pasientens bukser. Etter flere timers eksponering pådro han seg andre- og tredjegrads etseskade på begge legger tilsvarende ca. $5 \%$ av kroppsoverflaten. Sårene ble revidert flere ganger før endelig behandling med delhudstransplantat. Bildet er tatt seks dager etter innkomst og viser etseskader på begge legger etter flere sårrevisjoner.

Alkalisk etseskader grunnet kontakt med våt sement er en kjent, men relativt uvanlig årsak til etseskade. Våt sement er alkalisk, med $\mathrm{pH}$ på 10-14. Skaden er ofte smertefri initialt. Fravær av symptomer gjør at man kan bli eksponert over flere timer og utvikle hudnekroser (1). Andre- og tredjegrads etseskader er derfor vanlig. Sementbetingede hudskader ses oftest blant bygningsarbeidere og rammer hyppigst legger og knær. Tørr sement kan også gi etseskade ved kontakt med svett hud. Akutt behandling er å børste vekk tørr sement, deretter rikelig skylling med lunkent vann i opptil to timer før revisjon av nekrotisk hud. Det kan ta $12-48$ timer før det endelige omfanget av skaden er klart, og skadene krever ofte flere sårrevisjoner før eventuell hudtransplantasjon.

Pasienten har gitt samtykke til at artikkelen blir publisert.

\section{Steffen Waage}

steffenwaage@hotmail.com

John Christian Glent

Kirurgisk avdeling

Ringerike sykehus
Steffen Waage (f. 1974) er konstituert overlege. Forfatter har fylt ut ICMJE-skjemaet og oppgir ingen interessekonflikter.

John Christian Glent (f. 1983) er lege i spesialisering.

Forfatter har fylt ut ICMJE-skjemaet og oppgir ingen interessekonflikter

\section{Litteratur}

1. Alam M, Moynagh M, Lawlor C. Cement burns: the dublin national burns unit experience. J Burns Wounds 2007; 7: e4

Mottatt 27.11.2013 og godkjent 27.1.2014. Redaktør: Matilde Risopatron Berg.

Engelsk oversettelse på www.tidsskriftet.no 